\title{
Effect of Foliar Nutrition on Yield and Quality of Blackgram Growing as Augmenting Crop under Rice Fallow Condition
}

\author{
S. Vijay Kumar ${ }^{1 *}$, G. Srinivasan ${ }^{2}$, S. Pazhanisamy ${ }^{1}$ and K. Thanunathan ${ }^{3}$ \\ ${ }^{1}$ Dr.RPCAU, Pusa, Samastipur, Bihar- 848 125, India \\ ${ }^{2}$ Department of Agronomy, Agricultural College and Research Institute, Tamil Nadu \\ Agricultural University, Coimbatore, India \\ ${ }^{3}$ Department of Agronomy J.S.A College of Agriculture and Technology, India \\ *Corresponding author
}

\begin{tabular}{l} 
Ke y w o r d s \\
Rice fallow \\
blackgram, Foliar \\
nutrition, DAP, \\
Panchagavya, NAA, \\
Chelated \\
Micronutrient \\
\hline Article Info \\
$\begin{array}{l}\text { Accepted: } \\
\text { 18 March } 2020 \\
\text { Available Online: } \\
\text { 10 April } 2020\end{array}$ \\
\hline
\end{tabular}

The field experiment was conducted during rice fallow season (February -March, 2017) for foliar nutrition on growth and yield maximization of blackgram growing as augmenting crop under rice fallow condition. This experiment had eleven treatments was laid in Randomized Block Design with three replications viz., Control $\left(\mathrm{T}_{1}\right), 2 \%$ DAP foliar spray $\left(\mathrm{T}_{2}\right), 3 \%$ Panchakavya foliar spray $\left(\mathrm{T}_{3}\right), 40 \mathrm{ppm}$ NAA foliar spray $\left(\mathrm{T}_{4}\right), 2 \%$ Chelated micronutrient foliar spray $\left(\mathrm{T}_{5}\right), 2 \%$ DAP + $3 \%$ Panchakavya foliar spray $\left(\mathrm{T}_{6}\right), 2 \%$ DAP $+40 \mathrm{ppm}$ NAA foliar spray $\left(\mathrm{T}_{7}\right), 2 \%$ $\mathrm{DAP}+2 \%$ Chelated micronutrient foliar spray $\left(\mathrm{T}_{8}\right), 2 \%$ DAP $+3 \%$ Panchakavya $+40 \mathrm{ppm}$ NAA foliar spray $\left(\mathrm{T}_{9}\right), 3 \%$ Panchakavya $+40 \mathrm{ppm}$ NAA $+2 \%$ Chelated micronutrient foliar spray $\left(\mathrm{T}_{10}\right)$ and $2 \% \mathrm{DAP}+3 \%$ Panchakavya $+40 \mathrm{ppm}$ NAA + $2 \%$ Chelated micronutrient foliar spray $\left(\mathrm{T}_{11}\right)$ at 30 and 45 DAS. Among the all treatments the foliar application of $2 \%$ DAP $+3 \%$ Panchakavya $+40 \mathrm{ppm}$ NAA + $2 \%$ Chelated micronutrient foliar spray $\left(\mathrm{T}_{11}\right)$ at 30 and 45 DAS recorded the higher grain yield of $791 \mathrm{~kg} \mathrm{ha}^{-1}$ and haulm yield of $2219 \mathrm{~kg} \mathrm{ha}^{-1}$. The control $\left(\mathrm{T}_{1}\right)$ recorded the lower grain yield of $455 \mathrm{~kg} \mathrm{ha}^{-1}$ and haulm yield of $1562 \mathrm{~kg} \mathrm{ha}^{-1}$.

\section{Introduction}

Rice and blackgram are the most popular crops in deltaic zone of Tamil Nadu. Due to uncertain monsoon, rice cultivation in deltaic zone is not profitable and most of the farmers leave their land as fallow. The only option available to the farmers is to explore the pulse cultivation under poor soil fertile and moisture stress condition. Among the pulses, blackgram (Vigna mungo L.) is grown well under residual soil moisture condition. One of the important reasons of low productivity is poor fertility of soil. The problem is compounded by the majority of the farmers grow as dry (residual soil moisture) crop. 
They generally do not apply recommended dose of fertilizers. Farmers of deltaic zone of Tamil Nadu grow blackgram without application of fertilizers or use less than recommended dose of macro and micro nutrients.

This imbalanced nutrient supply adversely affects the seed yield of blackgram, soil health and even the profit to the farmers. To overcome this situation we have to move to alternate fertilizer application method.

Among all fertilizer application methods, foliar fertilization is more suitable under moisture stress condition and also farmers can easily adopt this method efficiently.

Manonmani and Srimathi (2009) have been reported that foliar application is credited with the advantage of quick and efficient utilization of nutrients, elimination of losses through leaching and fixation and regulating the uptake of nutrients by plants.

Writer (1986) reported that the physiological problem like flower drop and premature shedding of reproductive structure which seems to be associated with nutrient deficiency and hormonal imbalance and ultimately with the reduced translocation of dry matter to reproductive parts.

The growth regulating chemicals can improve the physiological efficiency including the photosynthetic ability of crop and play a significant role in improving the productive potential of the crop, so application of growth regulators through foliar spray at appropriate stages of growth become important for their efficient utilization and better performance of the crop (Ramesh and Ramprasad, 2013).

Consequently, applications of nutrient elements through foliar spray at appropriate stages of growth become important for their efficient utilization and better performance of the crop as a balanced fertilization with nutrients in plant nutrition is very important in the production of high yield with high quality seeds (sawan et al., 2001). It has been well established that the fertilizer elements which are absorbed through roots can also be absorbed with equal efficiency through foliage (Ganapathy et al., 2008).

Hence the response of blackgram on foliar spray of chelated micronutrient, panchakavya, DAPS and plant growth regulator study was taken on priority to see the effect of foliar nutrition on blackgram in under residual moisture condition.

\section{Materials and Methods}

Field experiment was conducted at the Experimental Farm, Department of Agronomy, Annamalai University, Annamalai Nagar to study effect of foliar nutrition on yield and quality protein content of blackgram under rice fallow blackgram cropping system, during February- April, 2017.

The experimental farm is geographically situated at $11^{\circ} 24^{\prime}$ North Latitude and $79^{\circ} 44^{\prime}$ East Longitude at an altitude of $+5.79 \mathrm{~m}$ above mean sea level. The soil of the experimental site was Clay loam having $\mathrm{pH}$ (7.4), EC $\left(0.51 \mathrm{dSm}^{-1}\right)$,

Organic carbon $(0.54 \%)$, low available $\mathrm{N}$ (224 kg ha- $\left.{ }^{1}\right)$, medium available P $(13.89 \mathrm{~kg}$ ha- $\left.^{1}\right)$ and high $\mathrm{K}\left(287 \mathrm{~kg} \mathrm{ha-}{ }^{1}\right)$. The experiment was laid out in a Randomized Block Design with 11 treatments.

The treatments viz., Control $\left(\mathrm{T}_{1}\right), 2 \%$ DAP foliar spray $\left(\mathrm{T}_{2}\right)$, 3\% Panchakavya foliar spray $\left(\mathrm{T}_{3}\right), 40 \mathrm{ppm}$ NAA foliar spray $\left(\mathrm{T}_{4}\right), 2 \%$ Chelated micronutrient foliar spray $\left(\mathrm{T}_{5}\right), 2 \%$ DAP $+3 \%$ Panchakavya foliar spray $\left(\mathrm{T}_{6}\right)$, $2 \% \mathrm{DAP}+40 \mathrm{ppm}$ NAA foliar spray $\left(\mathrm{T}_{7}\right), 2 \%$ 
DAP + 2\%Chelated micronutrient foliar spray $\left(\mathrm{T}_{8}\right), 2 \% \mathrm{DAP}+3 \%$ Panchakavya $+40 \mathrm{ppm}$ NAA foliar spray $\left(\mathrm{T}_{9}\right), 3 \%$ Panchakavya + 40 ppm NAA $+2 \%$ Chelated micronutrient foliar spray $\left(\mathrm{T}_{10}\right), \quad 2 \% \mathrm{DAP}+3 \%$ Panchakavya $+40 \mathrm{ppm}$ NAA $+2 \%$ Chelated micronutrient foliar spray $\left(\mathrm{T}_{11}\right)$ at 30 and 45 DAS with 3 replications using VBN-5 variety.

Seeds were broadcasted and maintained optimum plant population at $30 \mathrm{X} 10 \mathrm{~cm}$ spacing in the rice harvested field by thinning and gap filling process. The nitrogen content of grain was estimated by Micro kjeldhal method (Humphries, 1956).

Then total nitrogen was multiplied by a constant factor 6.25 to obtain crude protein content and expressed in percentage. The data were analyzed statistically using the ' $F$ ' test and critical difference (C.D) was calculated.

\section{Results and Discussion}

There was no significant difference up to flowering stage among the treatments except absolute control $\left(\mathrm{T}_{1)}\right.$ realizing the importance of nutrition. There were significant differences observed among all the treatments when foliar nutrition was given.

Among the different treatments, foliar application of $2 \%$ DAP $+3 \%$ Panchakavya + 40ppm NAA $+0.5 \%$ Chelated micronutrient at 30 and 45 DAS $\left(\mathrm{T}_{11}\right)$ recorded higher number of pods plant ${ }^{-1}$ on blackgram.

The increase in number of pods plant ${ }^{-1}$ might be due to supplementation of nutrients at the critical stage without physiological stress. Foliar application of nutrients enhanced the number of floral buds, prevented the floral shedding by maintaining optimum biophysiological conditions in plants. The present finding is in line with the reports of Uma Maheswari and Karthik (2017). Among the different treatments, foliar application of $2 \%$ DAP + 3\% Panchakavya + 40ppm NAA + $0.5 \%$ Chelated micronutrient at 30 and 45 DAS $\left(\mathrm{T}_{11}\right)$ recorded higher number of seeds $\operatorname{pod}^{-1}$ on blackgram. This might be due to increasing pod length by application of NAA (Foysalkabir et al., 2016).

Foliar application of macro and micro nutrients at reproductive stage was significantly influenced the translocation of photosynthates and ultimately it helped to better filling of seeds in pods (Vijaysingh Thakur et al., 2017).

Among the different treatments, foliar application of $2 \%$ DAP $+3 \%$ Panchakavya + 40ppm NAA $+0.5 \%$ Chelated micronutrient foliar spray at 30 and $45 \mathrm{DAS}\left(\mathrm{T}_{11}\right)$ recorded significantly higher grain yield in blackgram.

This might be due to adequate supply of nutrients at different growth stages of the crop which helped in better absorption and translocation into the plant system more efficiently contributing to developing pods and proper filling up of seeds thereby resulting in higher grain yield.

The least grain yield recorded under control $\left(\mathrm{T}_{1}\right)$ might be due to lack of adequate supply of phosphorus and nitrogen to the crop which in turn affected the growth and yield components of the crop ultimately reflecting on yield.

The present results are in agreement with earlier findings of Shashikumar et al., (2013), Marimuthu and Surendran (2015), Muthal et al., (2016), Ramesh et al., (2016) and Siva et al., (2017) (Table 1, Fig. 1 and 2). 
Table.1 Effect of foliar nutrition on yield components, grain yield and seed protein content of rice fallow blackgram

\begin{tabular}{|c|c|c|c|c|c|c|}
\hline Treatments & $\begin{array}{l}\text { Number } \\
\text { of pods } \\
\text { plant }^{-1}\end{array}$ & $\begin{array}{l}\text { Number } \\
\text { of seeds } \\
\text { pod }^{-1}\end{array}$ & $\begin{array}{l}\text { Pod } \\
\text { length } \\
(\mathrm{cm})\end{array}$ & $\begin{array}{l}\text { Grain } \\
\text { yield }\end{array}$ & $\begin{array}{l}\text { Haulm } \\
\text { yield }\end{array}$ & $\begin{array}{l}\text { Seed } \\
\text { protein } \\
(\%)\end{array}$ \\
\hline $\mathbf{T}_{1}-$ Control. & 21.1 & 5.3 & 4.26 & 455 & 1562 & 20.36 \\
\hline$T_{2}-2 \%$ DAP foliar spray at 30 and 45 DAS. & 23.6 & 5.7 & 4.48 & 498 & 1658 & 21.23 \\
\hline $\begin{array}{l}T_{3}-3 \% \text { Panchakavya foliar spray at } 30 \text { and } 45 \\
\text { DAS. }\end{array}$ & 26.8 & 6.4 & 4.86 & 593 & 1814 & 22.93 \\
\hline$T_{4}-40 p p m$ NAA foliar spray at 30 and 45 DAS. & 26.1 & 6.4 & 4.78 & 577 & 1788 & 22.81 \\
\hline $\begin{array}{l}\mathrm{T}_{5}-0.5 \% \text { Chelated micronutrient foliar spray at } \\
30 \text { and } 45 \text { DAS. }\end{array}$ & 25.7 & 6.2 & 4.69 & 559 & 1752 & 22.56 \\
\hline $\begin{array}{l}T_{6}-2 \% \text { DAP }+3 \% \text { Panchakavya foliar spray at } \\
30 \text { and } 45 \text { DAS. }\end{array}$ & 28.9 & 6.9 & 5.09 & 642 & 1918 & 23.14 \\
\hline $\begin{array}{l}\mathrm{T}_{7}-2 \% \text { DAP + 40ppm NAA foliar spray at } 30 \\
\text { and } 45 \text { DAS. }\end{array}$ & 30.1 & 7.2 & 5.24 & 670 & 1991 & 23.37 \\
\hline $\begin{array}{l}\mathrm{T}_{8}-2 \% \text { DAP }+0.5 \% \text { Chelated micronutrient } \\
\text { foliar spray at } 30 \text { and } 45 \text { DAS. }\end{array}$ & 29.6 & 7.0 & 5.18 & 651 & 1956 & 23.23 \\
\hline $\begin{array}{l}T_{9}-2 \% \text { DAP }+3 \% \text { Panchakavya }+40 \mathrm{ppm} \text { NAA } \\
\text { foliar spray at } 30 \text { and } 45 \text { DAS. }\end{array}$ & 32.1 & 7.6 & 5.47 & 711 & 2085 & 23.84 \\
\hline $\begin{array}{l}\mathrm{T}_{10}-3 \% \text { Panchakavya }+40 \mathrm{ppm} \text { NAA }+0.5 \% \\
\text { Chelated micronutrient foliar spray at } 30 \text { and } 45 \\
\text { DAS. }\end{array}$ & 32.9 & 7.8 & 5.54 & 729 & 2123 & 23.97 \\
\hline $\begin{array}{l}\mathrm{T}_{11}-2 \% \text { DAP }+3 \% \text { Panchakavya }+40 \mathrm{ppm} \text { NAA } \\
+0.5 \% \text { Chelated micronutrient foliar spray at } 30 \\
\text { and } 45 \text { DAS. }\end{array}$ & 35.0 & 8.2 & 5.78 & 791 & 2219 & 24.33 \\
\hline S.Ed & 0.96 & 0.18 & 0.09 & 18.84 & 44.55 & 0.09 \\
\hline $\mathrm{CD}(\mathrm{p}=0.05)$ & 2.00 & 0.38 & 0.19 & 30.31 & 92.93 & 0.19 \\
\hline
\end{tabular}

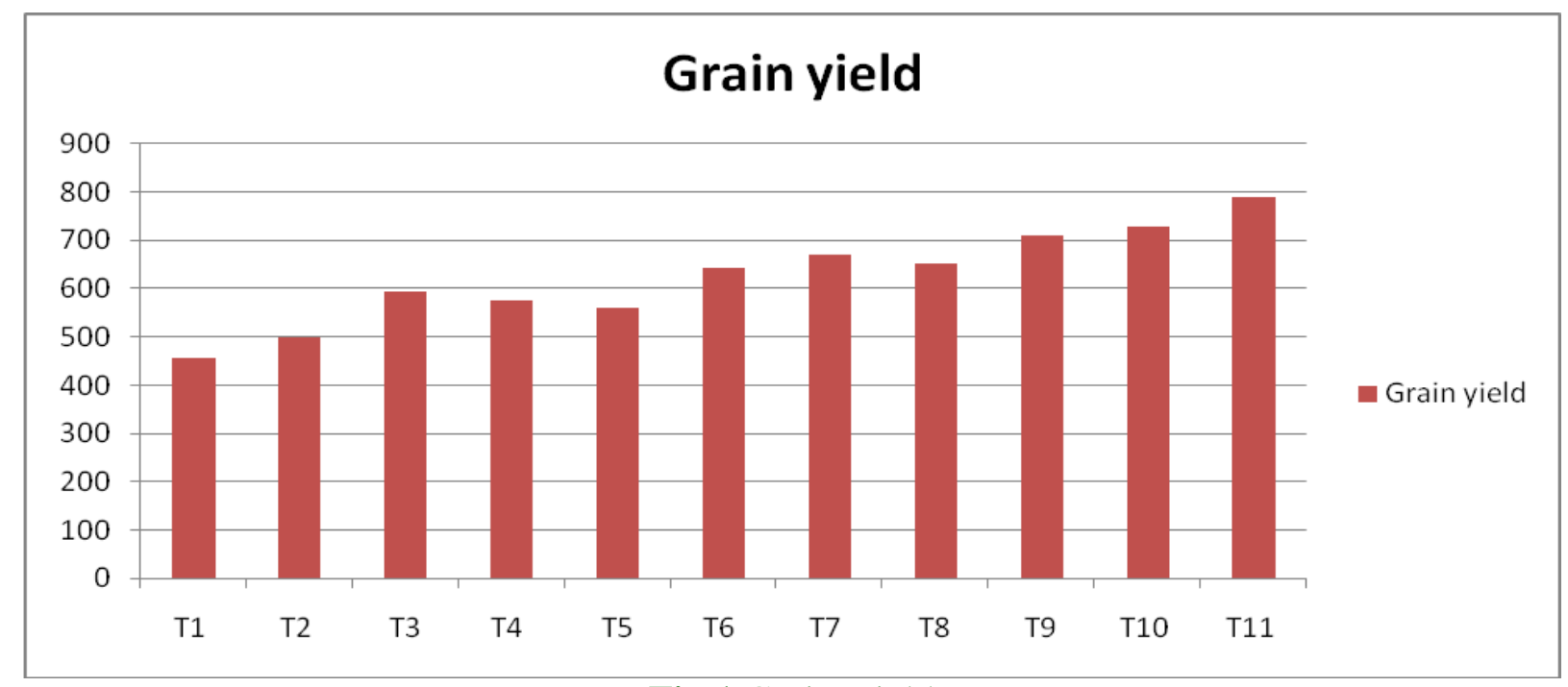

Fig.1 Grain Yield 


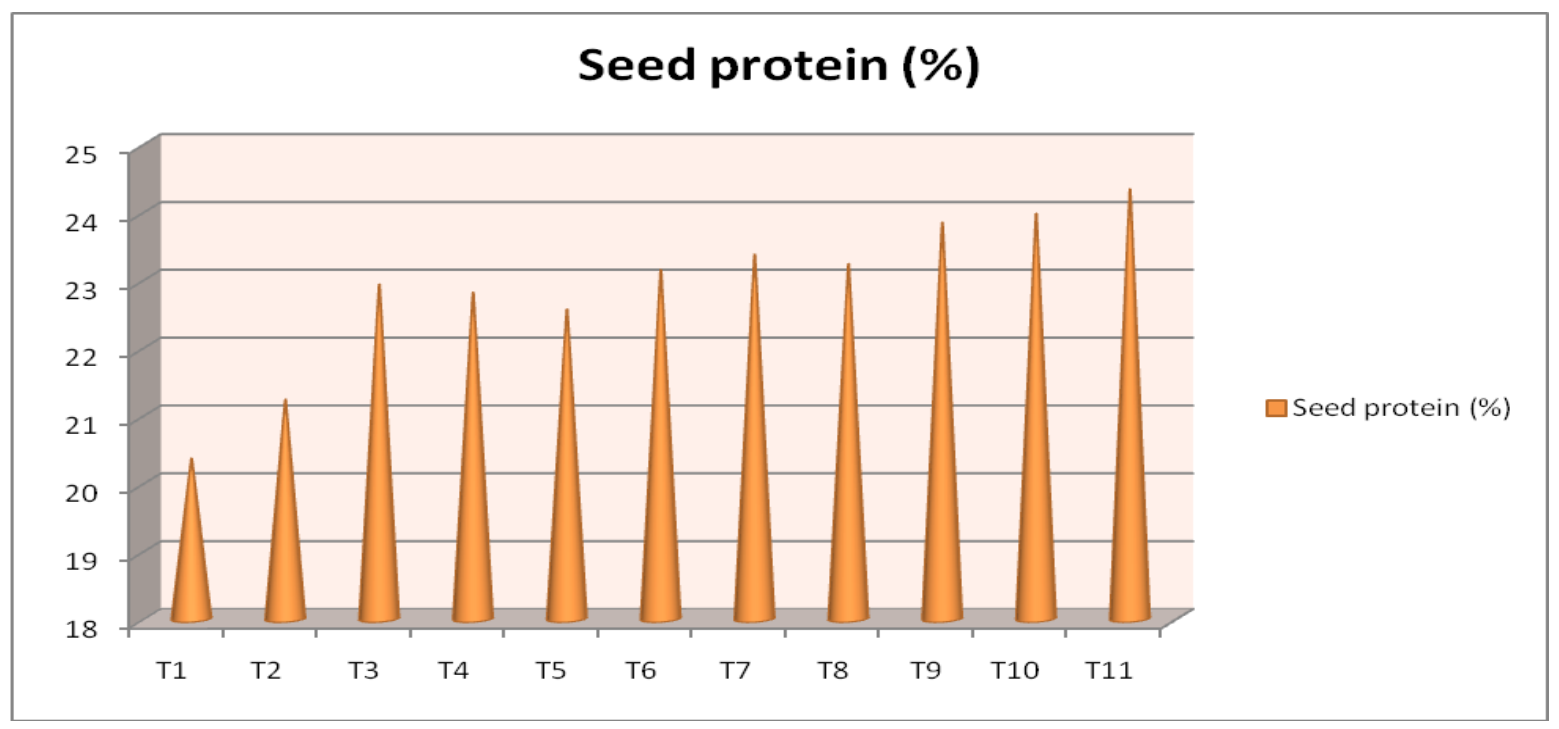

Fig.2 Seed protein (\%)

Based on the results of the present investigation, it can be concluded that foliar application of $2 \%$ DAP $+3 \%$ Panchakavya + $40 \mathrm{ppm} \mathrm{NAA}+0.5 \%$ Chelated micronutrient foliar spray at 30 and 45 DAS $\left(T_{11}\right)$ was found to be the highly benefited compared to all other treatment combinations, so I suggest that blackgram growing as augmenting crop in the rice - fallow condition with above combination of treatment considerably increased the productivity and seed protein content of blackgram.

\section{References}

Ganapathy, M., Baradhan, G. and Ramesh, N. 2008. Effect of foliar nutrition on reproductive efficiency and grain yield of rice fallow pulses. Legume Research, 31 (2): $142-144$.

Humphries, E.C. 1956. Mineral component and ash analysis. In: Modern methods of plant analysis, Springer Verlag, PP. 468-502.

Manonmani, V. and Srimathi, P. 2009. Influence of mother crop nutrition on seed and quality of blackgram. Madras Agricultural Journal, 96:125-128.

Marimuthu, S. and Surendran, U. 2015. Effect of nutrients and plant growth regulators on growth and yield of blackgram in sandy loam soils of Cauvery new delta zone, India. Cogent Food and Agri., 1: 1010415.

Muthal, Y.C., Deshmukh, S.L., Sagvekar, V.V. and Shinde, J.B. 2016. Effect of foliar application of macronutrient and micronutrients on yield attributes, yield and economics of kharif greengram (Vigna radiata L.). National Academy of Agricultural Science, 34 (7):21432149.

Ramesh, R and Ramprasad, E. 2013. Effect of plant growth regulators on morphological, physiological and biochemical parameters of Soybean. J. Helix., 6: 441-447.

Ramesh.T., Rathika, S., Parthipan, T. and Ravi, V. 2016. Productivity enhancement in blackgram through refinement of nutrient management under rice fallow condition. Legume Research, 39 (1): 106-109.

Sawan, ZM., Hafez, SA. and Basyony, AE. 2001. Effect of phosphorus fertilization and foliar application of chelated zinc and calcium on seed, protein and oil yields and oil properties of cotton. Journal of Agricultural Sciences, 136: 191-198. 
Shashikumar, R., Basavarajappa, S.R., Salkinkop, Manjunatha Hebber, Basavarajappa M.P. and Patil, H.Y. 2013. Effect of growth regulator, organic and inorganic foliar nutrition on the growth and yield of blackgram (Vigna mungo L.) under rainfed condition. Karnataka J. Agric. Sci., 26 (2): 311-313.

Siva, J., Hemalatha, M. and Joseph, M. 2017. Effect of Sowing Methods and Foliar Nutrition for Maximizing the Productivity of Rice Fallow Blackgram (Vigna mungo L.). Int.J.Curr.Microbiol.App.Sci., 6 (6) :
105-110.

Uma Maheswari M and Karthik A. 2017. Effect of foliar nutrition on growth, yield attributes and seed yield of pulse crops. Adv Crop Sci. Tech., 5 (3): 278281.

Vijaysingh Thakur, Patil, Patil, Suma and Umesh. 2017. Influence of foliar nutrition on growth and yield of blackgram under rainfed condition. Journal of Pharmacognosy and phytochemistry, 6(6): 33-37.

Writer, S.K. 1986. Outlook Agric., 6: 205217.

\section{How to cite this article:}

Vijay Kumar, S., G. Srinivasan, S. Pazhanisamy and Thanunathan, K. 2020. Effect of Foliar Nutrition on Yield and Quality of Blackgram Growing as Augmenting Crop under Rice Fallow Condition. Int.J.Curr.Microbiol.App.Sci. 9(04): 2494-2499.

doi: https://doi.org/10.20546/ijcmas.2020.904.298 